\title{
eSERVICES AS A CHALLENGE FOR SMALL MUNICIPALITIES - SLOVAK REPUBLIC EXPERIENCES
}

\author{
Silvia Ručinská ${ }^{1}$ and Miroslav Fečko ${ }^{2}$
}

DOI: $10.24989 /$ ocg.338.30

\begin{abstract}
Cities are using smart city and eGovernment solutions as modern trends also to enhance the management of the city and to get the citizens and entrepreneurs more engaged. Cities in the Slovak Republic are thus introducing ICT based services in order to cope with legal state obligations and also as a natural decision based on specific needs of the municipality. eGovernment developed and introduced on the national level by the state, combined with eServices at the municipality level, mutually lead to a modern, smart and better functioning city. The article is focused on current Slovak Republic's experiences in the field of eGovernment, more concretely on the provision of eServices in small municipalities, which make up the majority of the entire municipalities in the Slovak Republic.
\end{abstract}

Keywords: eGovernment, Smart City, Slovak Republic, Municipalities, Municipality Data Centre

\section{Introduction}

The increasing use of modern information communication technologies (ICT) in the public sector, especially in the contact between public authorities with citizens and entrepreneurs has led to modernisation of governmental system, processes, management, decision making processes, what we are referring to as eGovernment $[16,33,6]$. eGovernment has to find ways to use ICT in order to allow an interaction between the government and citizens in a way that such an interaction can be considered as equal participation and not only as one-way provision of information [18]. eGovernment can be seen as a system, which allows governments to improve in the areas of transparency, democratic participation, service orientation, productivity and for the local governments to provide seamless services [6]. eGovernment is understood as a platform interconnecting public administration institutions, employees, citizens, businesses, administration, whilst connecting these different subjects within well-known interactions as Government to Employee, Government to Government, Government to Citizen, Government to Business, Government to Administration [15]. The traditional government structure is due to eGovernment changing into a system of a greater citizen involvement, in line with the New Public Management paradigm [18].

eGovernment and eServices need to be distinguished between, what also Sainz de Abajo, B. S. et al. [34] has highlighted. According to different services, which eGovernment incorporates, eServices are only a partial element, together with eManagement, eDemocracy and ePolicy [34]. In the following text we will refer to eServices as to a service fully provided by using electronic means, with the ability

\footnotetext{
${ }^{1}$ Pavol Jozef Šafárik University in Košice, Faculty of Public Administration, silvia.rucinska@upjs.sk

${ }^{2}$ Pavol Jozef Šafárik University in Košice, Faculty of Public Administration, miroslav.fecko@upjs.sk
} 
to receive the result of the service also electronically. eGovernment will be seen as an entire system, which the eServices are a part of.

Municipalities have had naturally the tendency to take over these modern trends in order to enhance their own interorganizational functioning, but also and mainly in order to enhance the provision of services to the inhabitants and entrepreneurs living, residing in their territory. Sometimes these activities of the municipalities have the tendency to be declared as an effort to become a smart city. Otherwise the intention is limited only to the provision of municipality services by using ICT based modern technologies, and thus providing eServices. The distinction between the application of smart city concepts and application of ICT based tools in order to provide services reflecting a particular level of eGovernment, has to be taken into consideration.

eServices are designed through ICT [17] and establishing interface between the citizen and governments with the result of creating a value to someone [21]. eServices using electronic means, internet or any other ICT are applicable in the private, commerce sector as e-commerce and also in the public sector within the eGovernment [20]. More than often it is the public sector, which follows the trends well established in the private, commerce sector. If we are focusing on the public sector though, including state governmental level and self-government municipal or regional level, the intention to use eServices is mainly with the focus to "make our lives easier, more efficient, and bring less bureaucracy" [20] and also to increase the engagement of citizens and entrepreneurs [16]. More engaged community in a municipality, a municipality which is effectively using smart city solutions and which is able to mediate its eServices in a form near to the end user (citizen and entrepreneur mainly), can lead to a better functioning, effective, smart municipality which takes into account the needs of the local community and which makes use of modern ICT based technologies in a good way.

eGovernment in general is not seen as a challenge anymore. In the EU Member States it is well established and has become a daily routine of the public administration. In order for the eGovernment to be implemented, components and preconditions have to be fulfilled. The Digital Economy and Society Index (DESI) highlighted connectivity, human capital, use of internet services, integration of digital technology, digital public services as the main areas, which are considered and evaluated within the index dealing with different capabilities of the EU member states in the area of eGovernment [14]. Similar factors, as for example interaction of the population, societal pressure, measures and projects carried out by the government, ICT development, good management, gradual design, involvement of different parties, qualified and experienced team have been also concluded by Sainz de Abajo et al. [34], which can be considered as success factors of eGovernment use. The ability to fulfil different factors, criteria and components, consequently indicates how eGovernment is realised in concrete conditions.

The article is focused on the experiences of the Slovak Republic in the field of eGovernment, with a special emphasis drawn onto the self-government level and the provision of eServices by the municipalities. The intention won't be to present and to propose new approaches in the eGovernment, but to highlight experiences of the Slovak Republic in eGovernment, especially how small municipalities practically solve issues with regards to the provision of eServices, considering the factors, limits and preconditions they have in place. The aim will be to present organisational, administrative and legislative background of eGovernment and provision of eServices in the Slovak Republic, with the main orientation on the practice of provision eServices by the municipalities in the Slovak Republic. The Municipality Data Centre, as the tool for provision of eServices at the municipality level used by the vast majority of municipalities in the Slovak Republic will be in the foreground of the practice-oriented explanations. 
Activities in the area of eGovernment in the Slovak Republic started in 2001 by adopting the Policy for the Development of the Information Society in the Slovak Republic [13] followed by several steps, activities and measures in the field of eGovernment which have been gradually implemented. Our intention here will not be to present an in dept analysis of the history of eGovernment in the Slovak Republic, this topic is not any new. eGovernment in the Slovak Republic is according to the Digital Economy and Society Index (DESI) [14] scoring below the EU average, and it cannot be expected that the achieved results will be a presentation of highly innovative eGovernment approaches. The aim of the article is thus to evaluate the use and the applications of eServices as a part of the eGovernment in today's Slovak Republic's practice.

\section{2. eGovernment and eServices in the Slovak Republic's legislation and practice}

The competences, tasks and coordinating activities in the area of eGovernment and provision of eServices by the state government offices or self-government offices are distributed between different authorities in the Slovak Republic. The Office of the Deputy Prime Minister of the Slovak Republic for Investments and Informatization is the main state authority responsible for managing and coordinating of the informatization of the society including eGovernment [35]. Partially, leading state authorities in selected tasks are also the Ministry of Interior of the Slovak Republic with regards to the public administration, local state government and self-government, and the Ministry of Economy of the Slovak Republic with regards to innovations, supporting businesses using eServices and smart cities support $[23,24]$.

Organizational background of the state government offices is in the area of eGovernment supported by several legislation acts, from which the Act no. 305/2013 on the electronic form of provision of powers of public authority bodies and on amendments to certain acts (the eGovernment Act) is the main legislation determining eGovernment and provision of eServices by the state government and self-government authorities, including municipalities [1]. The Decree of the Ministry of Finance of the Slovak Republic no. 55/2014 about the standards for public administration information systems stated six levels of public administration electronic services, based on the level of electronisation. The 0 - Off line level means, that the electronic service is not available. Next step is the $1-$ Informative level, characterized by the electronic availability of information needed for the service, but the service itself, nor the form are provided electronically. One-way electronic communication, as the essence of the 2 - One-way interaction level means, that the form can be downloaded electronically, but the submission is only available physically. The 3 - Bidirectional interaction level contains the use of electronic means when providing a service, but the results of the service need to be take over physically or in paper form. Fully electronically available provision of services is achieved at the 4 - Transaction level, including taking over decisions and making necessary payments. The final 5 - Proactive level makes the functionalities of level 3 and level 4 available, including the possibility of a personalized and automated provision of a service [7].

The decentralization and deconcentration of public administration in the past decades in the Slovak Republic has led to a very complex system of competences, which the municipalities have to deal with. The municipalities in the Slovak Republic fulfil two kinds of competences, the original competences and the transferred competences. The original competences are the expression of tasks naturally connected to the provision of services for the inhabitants and dealing with everyday life in the municipality, focusing on the versatile development of the territory and on the needs of the inhabitants [2]. The provision of transferred competences is possible only based on a special legislative regulation, whereby the state government level transfers the provision of specific state government services onto the municipalities, controls this provision and finances it [3]. 
According to the Statistical Office of the Slovak Republic the entire population of the Slovak Republic amounting 5,4 million people lived in 2018 in 2890 municipalities. The majority of these municipalities, as shown in the Table 1 were small municipalities. This shows, that the settlement structure of the Slovak Republic is very fragmented [36, 37]. In combination with the same amount of self-government and transferred competences regardless of the size of a municipality, the small municipalities face big challenges in the provision of their services, especially of the eServices. Thus, the provision of services by electronic means can be considered as a challenge for small municipalities but also as a solution to cope with number of competences.

\begin{tabular}{|c|c|}
\hline $\begin{array}{c}\text { Size group according to the } \\
\text { number of inhabitants }\end{array}$ & Number of municipalities \\
\hline 99 or less & 404 \\
\hline $200-499$ & 720 \\
\hline $500-999$ & 760 \\
\hline $1000-1999$ & 570 \\
\hline $2000-4999$ & 301 \\
\hline $5000-9999$ & 63 \\
\hline $10000-19999$ & 34 \\
\hline $50000-49999$ & 28 \\
\hline $100000-99999$ & 8 \\
\hline
\end{tabular}

Table 1: Size groups of municipalities in the Slovak Republic (2018) Source: [37]

According to the eGovernment Act, public authorities, including municipalities regardless of their size were obliged to provide eServices starting from November $1^{\text {st }} 2016$ [1]. The exact form and specific electronic solutions weren't prescribed though. This has led to different solutions in different municipalities, taking into account the ability of a particular municipality to develop electronic solutions using its own potential or using market ready solutions, which the municipality is using as a service from a third party. Municipalities have not been reliant to discover appropriate solutions on themselves, but they coordinated activities within existing associations. The municipalities in the Slovak Republic are grouped into two main associations, the Association of Towns and Communities of Slovakia and the City Union. The goal of both organisations is to help municipalities and cities and also to offer and suggest solutions for the realisation of eGovernment at the local level.

The Association of Towns and Communities of Slovakia was established as a non-governmental organisation in 1990 and since then it associates municipalities and cities in the Slovak Republic focusing on common problems, challenges, tasks and needs of members. Altogether 2784 municipalities, including 131 cities in the Slovak Republic are currently members of the Association of Towns and Communities of Slovakia [4]. The City Union was established in 1994 with the focus to group cities in their common effort to protect the rights and interests of the cities, to present the importance of cities as regional centres and to support financial, institutional and tax sovereignty of cities. Altogether 48 cities in the Slovak Republic are currently members of the City Union [8].

Regardless of their size, financial strength or personal and organisational background, municipalities had to find appropriate solutions for providing eServices. The combination of municipality's effort and coordination of some activities within associating organizations resulted into different ways of coping with legislative obligations in the area of eServices. 


\section{3. eServices in Municipalities in the Slovak Republic}

Municipalities in the Slovak Republic are considered as public authorities in the sense of the eGovernment Act and thus, the necessity to provide services as eServices is fully applicable to every municipality, whereby the legislation doesn't differentiate between the size of a municipality. This means, that the capital city and also the smallest municipality in the Slovak Republic (the smallest municipality being the municipality Príkra with 12 inhabitants), have the same obligations to provide services by electronic means. The same obligations of the municipalities are facing not the same potential of the municipalities, whereby the bigger cities with bigger budgets and better organisational, financial, personal background are able to develop own solutions and to provide eServices more effectively. Small municipalities tend to move towards the usage of market ready solutions, which they are using as a service. The Municipality Data Centre is one of the readymade solutions for the municipalities, which is not the only one in the Slovak Republic, but which the vast majority of the municipalities are using.

The Municipality Data Centre is a cloud computing based solution, which was in 2011 supported as a joint project of the Ministry of Finance of the Slovak Republic and of the Digitalization Data Centre of Local and Regional Governments of Slovakia, which was created as an association of legal persons by the Ministry of Finance of the Slovak Republic and by the Association of Towns and Communities of Slovakia (as mentioned in the section 2, the association groups together the majority of all municipalities). The Municipality Data Centre aimed to provide a service for the municipalities, which allowed them to cope with necessary legislative obligations in provision of eServices, provide eServices in the field of original competences, manage eServices agenda interorganisationally and interact electronically with the government $[9,28,31]$.

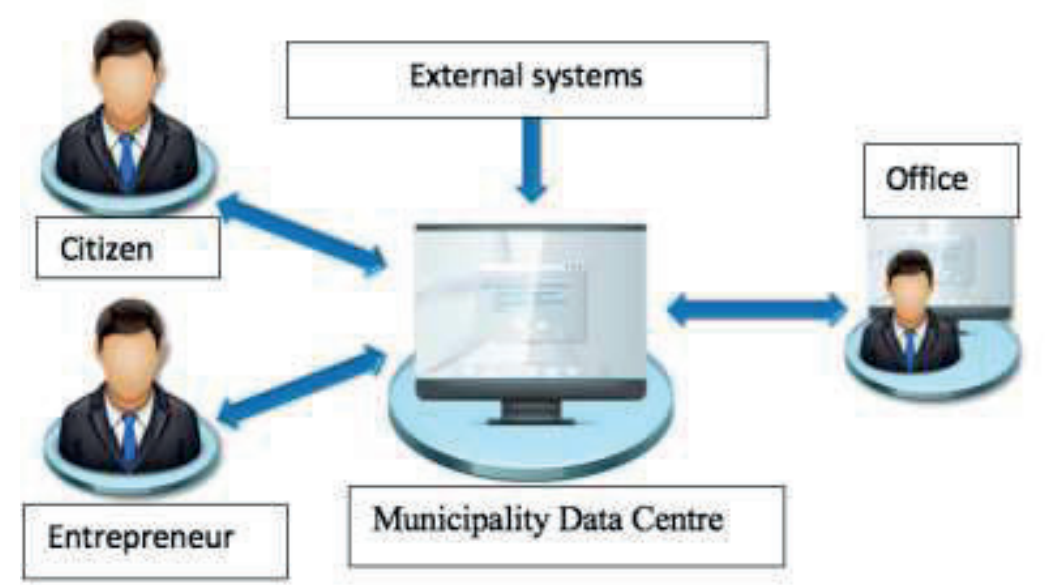

Figure 1: Complexity of interactions in the Municipality Data Centre Source: [30]

The Municipality Data Centre was designed as a complex system, which interconnects all relevant subjects and other existing government information systems, as shown in the Figure 1. The citizens and entrepreneurs have the access to eServices of a particular municipality within the original competences, with the possibility not only to send a submission, but also to receive the result. The Municipality Data Centre was created taking existing electronic solutions of the municipalities into consideration, which have been integrated into the new platform. The Municipality Data Centre also connects the municipality with existing state registries and information systems, as for example the register of natural persons, register of corporate entities, register of addresses, vehicle registry, 
property registry, etc., what takes away the need of a citizen, entrepreneur or the municipality to demand necessary information from another state government office [27, 30].

Altogether 138 eServices within the original municipality competences are provided using the Municipality Data Centre. Fully operational is the provision of eServices for citizens for example in the field of real estate tax, fees for municipal waste and minor construction waste, dog registration, voter ID card. Entrepreneurs have the possibility to use the Municipality Data Centre for example with regards to the payment of local taxes, processing of tax on the entry and stay of motor vehicles in a historical part of a town, issuing of parking cards, public procurement, permission process of specific operating hours [26, 27]. Based on the economic analysis it was assumed, that the Municipality Data Centre would be most suitable for smaller municipalities, up to 5000 inhabitants [32]. The municipalities are according to the accession agreement obliged to pay 1 Euro, for 1 inhabitant of the municipality, for 1 year [25]. This model of payment has been also one of the key economic factors, why especially small municipalities joint Municipality Data Centre. Bigger cities would have been obliged to pay an yearly amount, which would financially justify to consider financing own information systems. In 2018 the Municipality Data Centre was used by 2100 municipalities, what represented $71 \%$ of all municipalities, and altogether 2.25 million inhabitants had access to eServices. The Municipality Data Centre recorded 10 thousand users in 2018, with 600 hundred thousand submissions from the users and 1.1 million decisions send only for the year 2018 [9]. Fragmented spatial structure of the Slovak Republic with a big number of small municipalities resulted in the preference of a readymade solution for provision of municipality eServices in the form of the Municipality Data Centre.

The usage of the Municipality Data Centre brought several benefits to different subjects. Citizens and entrepreneurs benefited mainly from the 24/7 availability of the services, the submission can be made from whatever place and at whatever time, municipalities are obliged to cope with electronically received submissions and to respond also by using electronic means, the overall administrative procedures have been reduced, saving time with the reduction of physical visits of the local municipality office. The municipalities itself responded to the use of the Municipality Data Centre not only as a needed tool to cope with legislative obligations, but also as means for their own interorganizational effectiveness. Municipalities are benefiting from the availability of a software solution, without the need to deal with its development, administration and management. Municipalities got also a technical support from the provider, made use of a call centre in case of emergency or any questions regarding the operation, interconnection of existing registries and migration of data from previously used information systems were made possible, and further on, the benefits were also in effective workflows and interorganizational task management [28, 29].

As we pointed out, the Municipality Data Centre is not the only solution for provision of eServices, which the municipalities in the Slovak Republic are using. Lomtec company offered a product called ESMAO, which should provide a comprehensive solution for cities and municipalities in the area of eServices provision. ESMAO is offering 104 basic services, integration and interconnection to some central government registries (register of physical person, register of addresses, register of legal entities, central spatial information register), is offering mobile app support and is designed to support the existing information systems within the particular municipality, not to replace them [22, 10, 11]. The capital city of the Slovak Republic Bratislava and the second biggest city of the Slovak Republic Košice, have been among the first to implement solutions based on ESMAO [10]. Currently altogether 156 cities in the Slovak Republic, besides Košice and Bratislava, are using and have implemented the ESMAO solution for provision of eServices [12]. 
Bratislava and Košice are offering two types of services within their portals for eServices based on ESMAO, which are electronic submissions and electronic info services. Bratislava offers altogether 141 service, of which are 105 services offered as electronic services [5]. Košice offers altogether 101 services, from which are 60 electronic submission services [19]. We understand the electronic submission services as those, which comply with the essence of the eService described in the introduction of this paper, that means a service offering an output, result for the citizen, and not only an information available electronically.

\section{Conclusion}

Municipalities in the Slovak Republic took on the trend of adopting modern ICT based tools and solutions into their own activities and provision of their services. The reason of doing so was on the one hand and in the case of some municipalities a natural decision and on the other hand a need to cope with legislative obligations, which imposed every municipality to provide their services by electronic means. Municipalities, which are trying to naturally incorporate ICT based solutions in order to improve their management, processes, provision of services and to enhance the quality of life of the inhabitants doesn't need legislative obligations to be bound of doing something in this regard. The government of the Slovak Republic didn't rely only on naturally expressed tendencies and that's why legislative changes implying obligations in the field of provision of eServices came to place. The push of the legislator resulted in the necessity of every municipality in the Slovak Republic, regardless of the size and number of inhabitants, to provide services fully by using electronic means. This provision of eServices meant, that if the municipality receives a submission from a citizen or from an entrepreneur online, the result, output or the reply should be also done by the particular municipality online. For a service to be understood as an eService, real outputs, real values should be created in the form of a provided service, which solves an issue, issues a decision, and not only provides an electronically available information about the service.

The Municipality Data Centre has become the most widespread system for municipalities in provision of eServices in the field of original municipality competences. It was developed with a direct influence of the Association of Towns and Communities of Slovakia, which groups the majority of municipalities in the Slovak Republic. Taking the big number of small municipalities in the Slovak Republic into consideration, the Municipality Data Centre was a solution to be adopted for the majority of municipalities, because they couldn't be able to develop own and unique technical solutions within their own potential and "in house". At the same time, by using the Municipality Data Centre, the municipalities could fulfil the necessary legislative obligations. To provide eServices was a big challenge for the small municipalities. By using the Municipality Data Centre this challenge can result into a benefit, because also the smallest municipality can better manage complex and broad competences more effectively and to the benefit of the end users, the citizens and entrepreneurs.

\section{References}

[1] ACT NO. 305/2013 ON THE ELECTRONIC FORM OF PROVISION OF POWERS OF PUBLIC AUTHORITY BODIES AND ON AMENDMENTS TO CERTAIN ACTS (THE EGOVERNMENT ACT)

[2] ACT NO. 369/1990 ON MUNICIPAL ESTABLISHMENT, AS AMENDED 
[3] ACT NO. 416/2001 ON THE TRANSFER OF CERTAIN COMPETENCES FROM STATE ADMINISTRATION BODIES TO MUNICIPALITIES AND HIGHER TERRITORIAL UNITS, AS AMENDED

[4] ASSOCIATION OF TOWNS AND COMMUNITIES OF SLOVAKIA. ZMOS characteristics, activities and structure. Available at $<$ https://www.zmos.sk/zmos.html $>2019$.

[5] BRATISLAVA. Electronic services portal. Available at $<\mathrm{https}$ ://esluzby.bratislava.sk/info? page $=1>2020$.

[6] CEGARRA-NAVARRO, J.-G., CÓRDOBA PACHÓN, J. R. and MORENO CEGARRA, J. L., E-government and citizen's engagement with local affairs through e-websites: The case of Spanish municipalities. In: International Journal of Information Management, Volume 32, Issue 5, pp. 469-478. 2012. http://doi.org/10.1016/j.ijinfomgt.2012.02.008

[7] DECREE OF THE MINISTRY OF FINANCE OF THE SLOVAK REPUBLIC NO. 55/2014 ABOUT THE STANDARDS FOR PUBLIC ADMINISTRATION INFORMATION SYSTEMS

[8] CITY UNION. About the Union. Available at $<$ http://www.uniamiest.sk/o-unii $>2020$.

[9] DIGITALIZATION DATA CENTRE OF LOCAL AND REGIONAL GOVERNMENTS OF SLOVAKIA. Annual report 2018. Available at $<\mathrm{https} / /$ www.zdruzeniedeus.sk/documents/ 45051206/45052369/Výročná+správa+DEUS+2018> 2018.

[10] ESMAO. Čo je to ESMAO (What is ESMAO). Available at $<$ http://www.esmao.sk/stranka/coje-to-esmao> 2020a.

[11] ESMAO. Register (Registries). Available at <http://www.esmao.sk/stranka/registre $>2020 \mathrm{~b}$.

[12] ESMAO. Zoznam miest a obcí (List of towns and villages). Available at $<$ http://www. esmao.sk/zoznam-miest-a-obci> 2020c.

[13] EUROPEAN COMMISSION. eGovernment in Slovakia. Available at $<$ https://joinup.ec. europa.eu/sites/default/files/document/2015-03/egov_slovakia_-january_2015_-_v_17_0_

final.pdf $>2015$.

[14] EUROPEAN COMMISSION. Digital Economy and Society Index (DESI) 2019. Country Report Slovakia. Available at $<$ https://ec.europa.eu/newsroom/dae/document.cfm?doc_id= 59906> 2019.

[15] FABRYOVÁ, L., Informatizácia verejnej správy (Public administration informatization). In: The Office of the Deputy Prime Minister of the Slovak Republic for Investments and Informatization. Available at $<\mathrm{http}$ ://www.informatizacia.sk/egovernment/519s $>2011$

[16] FIETKIEWICZ, K. J., MAINKA, A. and STOCK, W. G., eGovernment in cities of the knowledge society. An empirical investigation of Smart Cities' governmental websites. In: Government Information Quarterly. Vol. 34, Issue 1, pp. 75-83. 2017. https://doi.org/10.1016/j. giq.2016.08 .003 
[17] GONZALEZ, R. A., FERRO, R. E. and LIBERONA, D., Government and governance in intelligent cities, smart transportation study case in Bogotá Colombia. In: Ain Shams Engineering Journal, Volume 11, Issue 1, pp. 25-34. 2020. doi.org/10.1016/j.asej.2019.05.002

[18] KOLACHALAM, S., An Overview of e-Government. In: Economia Aziendale Online. Business and Management Science International Quarterly Review. ISSN 2038-5498. No 1, Issue 1. pp. 1-12. 2004. doi.org/10.13132/2038-5498/2004.1.1-12b

[19] KOŠICE. Electronic services portal. Available at $<$ https://www.esluzbykosice.sk/info?page $=1>2020$.

[20] KVASNICOVA, T., KREMENOVA, I. and FABUS, J., From an analysis of e-services definitions and classifications to the proposal of new e-service classification. In: Procedia Economics and Finance, Vol. 39, pp. 192-196. 2016. doi:10.1016/S2212-5671(16)30282-9

[21] LINDGREN, I. and JANSSON, G., Electronic services in the public sector: A conceptual framework, 2013. In: Government Information Quarterly, (30), 2, pp. 163-172. 2013. http://dx.doi.org/10.1016/j.giq.2012.10.005

[22] LOMTEC. Electronic services of towns and municipalities. Available at $<$ https://www.lomtec. com/page/esmao-en> 2020 .

[23] MINISTRY OF ECONOMY OF THE SLOVAK REPUBLIC. About Ministry. Available at $<$ https://www. mhsr.sk/en/ministry/about-ministry> 2020.

[24] MINISTRY OF INTERIOR OF THE SLOVAK REPUBLIC. Available at $<$ http://www.minv.sk /?ministry-of-interior $>2020$.

[25] MUNICIPALITY DATA CENTRE. Amendment 1 to the Agreement on connection to the information system of the Municipality Data Centre. Available at <https://www.dcom. sk/documents/35486/0/Dodatok+č.+1+k+ZLP+2016_vzor+na+web.pdf/a8a8ced4-2e7d-42a28b10-66aaa9c070cb> 2016.

[26] MUNICIPALITY DATA CENTRE. eServices. Available at https://www.dcom.sk/en/esluzby 2020a

[27] MUNICIPALITY DATA CENTRE. Municipality Data Centre project layout. Available at $<$ https://www.dcom.sk/en/opis-modulov-pre-esluzby $>2020$ b

[28] MUNICIPALITY DATA CENTRE. National project Municipality Data Centre. Available at $<$ https://www.dcom.sk/en/narodny-projekt-dcom-v-ramci-opis $>2020 \mathrm{c}$

[29] MUNICIPALITY DATA CENTRE. Why is the project useful? Available at $<$ https://www.dcom. sk/en/preco-je-projekt-datove-centrum-obci-a-miest-uzitocny $>2020 \mathrm{~d}$

[30] PAVOL JOZEF ŠAFÁRIK UNIVERSITY IN KOŠICE. Methodology of the system for management public finances. Modul Municipality Data Centre. Training material. 2015. 
[31] PIERRE AUDOIN CONSULTANTS. White Paper. Data Centre Solutions - Successfully Delivering E-Government Services to Citizens. Available at $<$ https://www.posam.sk/wpcontent/uploads/2014/10/DataCenterSolutions-for-eGovernment-services-PAC-white-paper. $\operatorname{pdf}>2014$.

[32] POSAM. Aj občania menších obcí a miest budú môct' komunikovat' elektronicky (Also the inhabitants of smaller municipalities and cities will be able to communicate electronically). Available at <https://www.posam.sk/aj_obcana_mensch_obc_a-mest_budu_moct_komun kovat_elektroncky/> 2013.

[33] RÓISTE, M., Bringing in the users: The role for usability evaluation in eGovernment. In: Government Information Quarterly, Vol. 30. Issue 4. pp 441-449. 2013. https://doi.org/10 $.1016 /$ j.giq.2013.05.007

[34] SAINZ DE ABAJO B. et al. eGovernment: Real Democracy in Digital Society. In: CipollaFicarra F., Veltman K., Chih-Fang H., Cipolla-Ficarra M., Kratky A. (eds) Human-Computer Interaction, Tourism and Cultural Heritage. HCITOCH 2011. Lecture Notes in Computer Science, vol 7546. Springer, Berlin, Heidelberg. 2012. doi.org/10.1007/978-3-642-33944-8_10

[35] THE OFFICE OF THE DEPUTY PRIME MINISTER OF THE SLOVAK REPUBLIC FOR INVESTMENTS AND INFORMATIZATION. Deputy Prime Minister. About us. Available at $<$ https://www.vicepremier.gov.sk/en/podpredseda-vlady/about-us/> 2020.

[36] STATISTICAL OFFICE OF THE SLOVAK REPUBLIC. Demographic and social statistics. Population and migration. Stock and change of Population. Number of the Population by Sex SR, Areas, Regions, Districts, Urban, Rural (yearly) [om7102rr]. Available at: $<$ http://datacube.statistics.sk>2020a.

[37] STATISTICAL OFFICE OF THE SLOVAK REPUBLIC. Demographic and social statistics. Size Groups of Municipalities. Size Groups of Municipalities - SR-Area-Reg-District, U-R [om7023rr]. Available at: <http://datacube.statistics.sk>2020b 